\title{
A French C-test for language assessment
}

\author{
Oona Cromheecke \& Marc Brysbaert \\ Department of Experimental Psychology \\ Ghent University
}

Belgium

Keywords: vocabulary, French, language proficiency, C-test, second language, Lextale-FR

Address: Oona Cromheecke

Department of Experimental Psychology

Ghent University

H. Dunantlaan 2

B-9000 Gent

Belgium

Tel: +3292649425

Email: oona.cromheecke@gmail.com 


\section{Résumé}

Des tests de compétence linguistique sont souvent nécessaires pour des évaluations dans l'enseignement et la recherche, en particulier dans les contextes de langue seconde. Les tests de vocabulaire donnent des estimations rapides et utiles de la compétence linguistique. Dans la présente étude, un C-test de français a été développé et testé sur 129 étudiants bilingues néerlandais-français. Le nouveau C-test a été comparé à un C-test existant et à un test de vocabulaire oui/non (Lextale-FR). De plus, les notes de certains élèves ont été comparées à leurs notes à l'examen de français. La cohérence interne du nouveau test était ICC $=0,8$ et le test corrélait $\mathrm{r}=0,7$ avec le $\mathrm{C}$-test existant. La corrélation avec les notes d'examen était $\mathrm{r}=0,5$ (validité du critère). La corrélation avec Lextale-FR était plus faible $(\mathrm{r}=0,3)$ et Lextale-FR était également moins corrélé avec les notes d'examen ( $\mathrm{r}=0,3)$, confirmant que le C-test mesure des compétences non couvertes par Lextale-FR.

(The C-test est gratuit à des fins éducatives et de recherche.) 


\section{A French C-test for language assessment}

Short language proficiency tests are often needed for low-stakes assessment in education and research, particularly in second language settings. Vocabulary tests are a good candidate; they give rapid, useful estimates of language proficiency. Ideally, several formats are available so that language proficiency can be measured independently of the method used. In the present study, a French C-test was developed and tested on 129 Dutch-French bilingual students. The newly developed C-test was compared to an existing (but not yet validated) C-test and a yes/no vocabulary test (Lextale-FR). In addition, for some students the scores were compared to their French end-of-term marks. Internal consistency of the new test was ICC $=.8$ and the test correlated $\mathrm{r}=.7$ with the existing $\mathrm{C}$-test. Correlation with end-of-term marks was $\mathrm{r}=.5$ (criterion validity). Correlation with Lextale-FR was lower $(\mathrm{r}=.3)$ and Lextale-FR also correlated less with exam marks $(\mathrm{r}=.3$ ), confirming that the $\mathrm{C}$-test measures skills not covered by Lextale-FR.

(The C-test is free to use for educational and research purposes.) 
There are several occasions on which it is interesting to have a rough idea of a person's language proficiency. This is the case when a language teacher wants to know the level of students starting a course or when a researcher wants to assess language skills of participants taking part in a study (Amenta et al., 2020). Proficiency tests are particularly needed in second language (L2) contexts, but there are also large individual differences in native language (L1) knowledge, ascribed to differences in the individual's neurocognitive learning system and in the communicative environment (Kidd et al., 2018). The evaluations are low-stakes, because they do not affect participants' careers or perspectives. They are simply meant as a snapshot of current performance. Users typically want such tests to be short (15 minutes max), but at the same time reliable and valid (i.e., a trustworthy indication of language knowledge).

\section{How to assess language proficiency?}

Vocabulary tests are often used as a first estimate of language skills, because they are short and correlate well with more profound assessments involving different modalities (listening, reading, speaking, writing) and different language aspects (such as correct word use in discourse and correct grammar use). Scores on a vocabulary test are further interesting, because they are an objective measure (Brysbaert, 2013; Tomoschuk et al., 2018), complementing subjective estimates of language proficiency (i.e., participants' estimates of their own language skills). Especially for people who are not particularly strong or weak, the correlation between objective and subjective estimates of language proficiency is rather low, partly because participants compare themselves to a restricted comparison group (e.g., the other L2 students in their class).

Zhang and Zhang (2020) published a meta-analysis of the relationship between vocabulary knowledge and L2 reading/listening comprehension. Based on 276 effects $(21,000$ participants) they reported an overall correlation of $r=.56$. Written tests were slightly better to 
capture reading comprehension than auditory tests $(r=.60$ vs. $r=.49)$, whereas the reverse was true for oral comprehension $(r=.52$ vs. $r=.60)$. So, vocabulary test to some extent seem to be modality-specific.

Zhang and Zhang (2020) also distinguished between three formats of vocabulary tests. The first involved meaning recognition: Recognizing the meaning of a target word among various alternatives in a multiple choice test. The second format was meaning recall, in which participants had to produce an L2 description or L1 translation of the target word. The final format was form recall, in which participants had to translate L1 words into L2. Zhang and Zhang (2020) reported a higher correlation of reading comprehension with meaning recall $(\mathrm{r}=$ .66) than with form recall $(\mathrm{r}=.55)$ and meaning recognition $(\mathrm{r}=.53)$. For listening comprehension, form recall $(\mathrm{r}=.63)$ was better than meaning recall $(\mathrm{r}=.58)$ and meaning recognition $(\mathrm{r}=.50)$. The authors explained their findings by pointing out that meaning recall is the most important process when one is reading an L2 text. For listening comprehension, they associated the importance of form recall with the difficulty to segment the continuous auditory input into individual spoken words.

A format not covered by Zhang and Zhang (2020) was form recognition. This test typically consists of a list of letter sequences from which participants have to select the words they know. To discourage the participants from saying yes to each letter sequence, pseudowords are included in the list and participants are warned that their scores will be corrected if they respond yes to these stimuli. Pseudowords are letter sequences that look like real words, but do not exist. An example in English could be beek.

Form recognition (the yes/no task) became popular in psycholinguistic research after Lemhöfer and Broersma (2012) published the freely available LexTALE tests for English, German, and Dutch. These tests comprised 40 words and 20 pseudowords and were meant for advanced L2 speakers. For Dutch-English bilinguals, the English LexTALE scores correlated 
.75 with translation scores (both L1-L2 and L2-L1) and .63 with scores on the Quick Placement Test. For Korean-English bilinguals, the correlations were lower (respectively .61 and .29). Other positive findings with form recognition were published by Harrington and Carey (2009). They observed that the scores on a form recognition test predicted placement decisions as well as the local placement tool consisting of grammar, writing, speaking and listening measures. Less encouraging data were published by McLean et al. (2020). These authors predicted English language comprehension in Japanese university students using four different test formats: form recognition (yes/no checklists), form recall, meaning recognition, and meaning recall. Although form recognition had the best reliability for short tests, it correlated less well with text comprehension. The highest correlation was $r=.67$ (for tests with more than 100 items). In line with Zhang and Zhang (2020), McLean et al. (2020) reported that the best predictor of reading comprehension was meaning recall $(\mathrm{r}=.78)$, followed by form recall $(\mathrm{r}=.75)$, and meaning recognition $(\mathrm{r}=0.71)$.

Although the literature on the 'best' format is informative (see also Read, 2000; Schmitt et al., 2020; Webb \& Nation, 2017), it risks missing important information. Validity is likely to depend on the proficiency level of the participants (e.g., early L2 learners vs. L1 speakers, children vs. adults) and the criterion one wants to predict. Meaning recall tasks (translating L2 words into L1) seem to be best to predict reading comprehension, but the same may not be true for the prediction of response times in a lexical decision experiment. Diependaele et al. (2013) reported a high correlation between scores on a yes/no test and the size of the word frequency effect in visual word identification, both in L1 and L2 English speakers.

The limitations of a single best test can be illustrated with the multitrait-multimethod approach in test theory (Campbell \& Fiske, 1959). This approach accepts that each test is an imperfect measure of the competence one tries to measure. A distinction is made between latent variables and manifest variables. Latent variables are the psychological constructs researchers 
want to assess (e.g., vocabulary knowledge or grammar knowledge). Manifest variables are the test scores obtained. These are the outcome of three influences: (1) the latent variable, (2) testspecific characteristics (which may be due to other latent variables), and (3) noise. Within this framework, the best way to measure a latent variable is not to search for a single best manifest variable (although this is important as well), but to use several tests that measure the latent variable in different ways. If the tests address the same construct, they will correlate with each other. Because the tests also include test-specific aspects, the intercorrelations will be lower than the tests' reliabilities (which in turn estimate the degree of noise in the scores). The test specific aspects are due to the fact that tests are unlikely to load on only one latent variable. As we have seen above, the higher correlation between written vocabulary tests and reading comprehension than between spoken vocabulary tests and reading comprehension suggests that scores on vocabulary tests also load on a modality-specific factor (written vs. spoken language). Otherwise we cannot understand why correlations are higher when tasks are performed in the same modality than in different modalities (Zhang \& Zhang, 2020).

The multimethod perspective changes research dynamics. Instead of fighting over which test is best and whether a new test is better than what is available, researchers are encouraged to look for divergences and convergences among multiple tests to achieve a more detailed image of the underlying skills (latent variables). Ideally one has access to a multitude of tests and tasks tapping various parts of language proficiency and related skills (e.g., learning efficiency or crystallized intelligence), which should be the long-term goal of language proficiency research.

Of course, the multitrait-multimethod approach requires the availability of several tests in different formats, as illustrated by Zhang and Zhang (2020) and McLean et al. (2020). The finding that form recognition (yes/no task) does not predict language comprehension particularly well, indicates that an extra test for this competence is warranted. An obvious 
candidate is meaning recall (explaining L2 words or translation from L2 into L1). However, this task is known to be difficult to mark and to run, as participants tend to produce a wide range of (more or less) acceptable answers with lots of spelling errors in written modality (Laufer \& Aviad-Levitzky, 2017). This usually requires manual scoring by at least two independent markers (who in the case of L2-L1 translations also must have knowledge of participants' L1). Therefore, we decided to test another format that has been proposed as a particularly good predictor of language proficiency: The C-test.

\section{The C-test}

The C-test is a variant of the cloze format. In cloze tests, participants are given sentences/texts with missing bits of information. Initially, the test was developed to measure the readability of texts. Every $\mathrm{n}^{\text {th }}$ word of a text was deleted and readers were asked to fill in the missing words. The fewer words could be completed the more difficult the text was. Rapidly, however, the test was adapted to measure the proficiency of the test taker rather than the difficulty of the text used (Oller, 1973). So, participants would be asked to complete a text like: "The C-test is a variant of cloze tests. In cloze participants are

sentences/texts with bits of .” The number of sensible completions was taken as a measure of language proficiency. It correlated reasonably well with other measures of language proficiency.

A disadvantage of the original cloze format was that several continuations were acceptable, putting high demands on the scoring and introducing an element of subjectivity. Another problem was that the difficulty of the test depended substantially on the words deleted. These and other problems convinced Klein-Braley and Raatz (1984) to create the Ctest. It is still a cloze test, but the answers are much more constrained and proficient language users agree on the solution. The test consists of four to five short texts of 50 to 100 words. The first sentence is presented in full and then the second half of each second word is deleted. 
The test-taker has to complete the missing halves of those words. Applied to the example text above, the C-test looks as follows: "The C-test is a variant of cloze tests. In cl__tests, partic are gi sentences/texts wi missing bi of infor ." Correct answers not only require vocabulary knowledge but also grammatical and morphological knowledge to write the correct word form (this is more demanding in French than in English) and even text understanding to know which words are needed to form a coherent message. The texts are arranged in order of difficulty with the easiest texts first, to make the test useful for a wider range of proficiencies. Completion time is limited.

In several studies, the C-test was shown to be a good measure of L2 language proficiency (Daller et al., 2020). Related to English L2, Eckes and Grotjahn (2006) reported that scores on the test correlate $.5-.8$ with more extensive placement tests, such as TOEFL. Harsch and Hartig (2015) reported that the C-test correlated more with listening and reading comprehension $(r=.74)$ than the yes/no vocabulary test $(r=.44)$. No study could be found in which the C-test was compared directly to a meaning recall task.

One reason why the C-test does well to predict L2 language comprehension, may be that the test format combines two aspects of language proficiency: In-depth vocabulary knowledge and language processing speed. Participants have to know the words and they have to complete the test under time pressure (Daller et al., 2020). A second reason for the good performance of the test may be that the test measures syntactic knowledge and text understanding in addition to single word knowledge. A third reason may be that it involves language production rather than language perception (Zhang \& Zhang, 2020). Participants have to recall the correct responses; it is not enough to recognize it among the alternatives provided. Finally, the test may do well in L2 research because it is a written test and L2 knowledge is largely acquired in visual modality. 
Because of the various subskills measured, the C-test is one of the best formats to predict study success of (international) students, be it in an academic or a training context (Daller et al., 2020; Eckes \& Grotjahn, 2006; Harsch \& Hartig, 2015). Still, it has not yet enjoyed the popularity of vocabulary tests, arguably because it was not considered a 'pure' vocabulary test (e.g., Chapelle, 1994). If one wants to have an estimate of vocabulary size (as one component of language proficiency), the $\mathrm{C}$-test includes too many possible confounds. The same is true for a researcher looking for a pure measure of syntactic knowledge or text understanding. On the other hand, because of its high predictive value for language proficiency and study success, the test offers an interesting addition within the multitraitmultimethod perspective: How well does it measure vocabulary knowledge and what other skills are involved? In the present paper we describe the development and validation of a French C-test, so that research in this language can contribute to the literature.

\section{Language proficiency tests in French}

As in many other languages, there are surprisingly few vocabulary tests in French freely available for research, partly because language researchers almost never seem to include the tests in the articles they write about their tests. ${ }^{1}$ With respect to multiple-choice tests, Batista and Horst (2016) and Peters, Velghe, and Van Rompaey (2019) made reliable tests available for French L2. Because the Peters et al. test is limited to the 5,000 most frequent words, it is likely to be too easy for native speakers and advanced L2 speakers. Batista and Horst (2016) include 30 items that are more difficult.

\footnotetext{
${ }^{1}$ The tests we describe can be downloaded from https://www.iris-database.org/iris/app/home/index.
} 
Brysbaert (2013) published a yes/no test, called Lextale-FR. It includes 56 French words of increasing difficulty and 28 nonwords, and can be used both for L2 speakers and native speakers (for further details, see below).

We were not able to find a freely available, validated C-test in French. The best reference we could find, was a test developed by Raatz, Grotjahn and Wockenfuß (2006), which can be downloaded and consists of five paragraphs with a correction key. Unfortunately, no information is given about the reliability or validity of the test. As it was developed by a group of German researchers heavily involved in the development of C-tests for various languages, we decided to try it out, but to supplement it with a new test.

A second C-test is interesting for two reasons. First, the availability of two parallel tests allows researchers to test participants twice without repeating the stimuli (e.g., once before an intervention and once after). Second, tests involve choices that may limit their use. For vocabulary tests, this is the selection of target words (and response alternatives). Words may be better known to some groups and, therefore, inadvertently favor one group over the other. In C-tests, the topics of the texts may introduce additional bias, as not all groups may be equally familiar with all topics. A way to address this problem is to look at the convergent validity of two tests developed by independent research groups.

All in all, we had access to two C-tests, which we could correlate with Lextale-FR scores and (for a subset of participants) with exam marks.

\section{Method}

\section{Participants}

Participants included two groups: 115 high school students (aged between 16 and 18, mean age $=16.8$ ) and 14 first-year university students reading 'Applied Linguistics - French' (aged 
between 17 and 26, mean age=18.4). All participants were Dutch native speakers, who had taken compulsory French courses since the age of 10 (year 5 of primary school). The high school students took general education classes with 3-4 hours of French per week: 98 were in their last year (i.e., close to entering higher education) and 17 were $5^{\text {th }}$ year students (i.e., one year younger). The high school students came from eight different classes in three different schools. The university students were added to have information about more advanced L2 speakers. They were studying for a French degree and were expected to perform better on average than the high school students (David, 2016). Testing happened in October (i.e., at the beginning of the school year).

\section{Materials}

We presented three tests. The first was a new C-test we developed. It consisted of five paragraphs (Appendix A). In each paragraph 20 words had to be completed in the format described by Klein-Braley and Raatz (1984). The first sentence was given in full to introduce the topic. There was also a title introducing each topic. Then, sentences were presented in such a way that the second word half was missing for every second word. The missing letters were represented by empty boxes. When the target word had an odd number of letters, the

smaller part was given. So, the word green would be presented as $g r$ (two letters out of five). The paragraphs were taken from the website https://www.podcastfrancaisfacile.com/, written by Vincent Durrenberger, a French teacher educating children, adults, students, employees... from all levels. On the website visitors can read short texts and listen to them via audio tapes. Afterwards, questions can be answered to test how much the person understood from the text. Visitors of the website can choose from different themes, domains, skills and levels. The availability of different levels made it straightforward to select texts 
with increasing difficulty. The author gave written permission to use and adjust the five texts that were chosen to make the new C-test. The five topics were: Eiffel Tower, Wolves in France, April Fools' day, Valentine's day, and Trash on the beach. These topics were chosen because we assumed all students to be familiar with them. We did not correct the original paragraphs for possible cognates (in Dutch or other languages), as that would have made the texts less representative.

The second test was the C-test developed by Raatz et al. (2006). It also contained five paragraphs (Appendix B) with 20 words that had to be completed. There were two small issues with the test: 1) It contained two items with two possible answers instead of one, because both the singular and the plural form of the word were possible; 2) It did not always follow the original completion rule of Klein-Braley and Raatz (1984). Sometimes there was one letter extra or too little. We left these as they were. While piloting the test, we also noticed that the first text was more difficult than the other texts. Therefore, we shifted the first paragraph to the end. The topics covered were: holidays, exams, consulting a medical doctor, food industry, and agriculture. There were no paragraph titles in this test.

The final test was Lextale-FR, as described in Brysbaert (2013; see also Appendix C). Participants were shown 84 letter strings and had to decide for each whether it represented a French word they knew or not. Participants were warned that some letter strings were madeup words that do not exist in French, and that they would be penalized if they chose them.

\section{Procedure}

All tests were presented online via the website http://wextor.org/wextor/en/, developed to make psychological testing easy (Reips \& Neuhaus, 2002). For both C-tests, the participants had to complete the missing word endings. For Lextale-FR they had to indicate whether the letter string was a French word they knew or a false/non-existing word. WEXTOR made it 
possible to measure (and limit) the time of the test, which was important for the C-tests. The online experiment was linked to a logbook, which kept track of the answers.

The experiment was slightly different for the high school students than for the university students. For the high school students, the experiment consisted of three tests; the new C-test, the existing C-test and Lextale-FR. For the university students the existing C-test was left out because of time demands. The high school students were tested at school during a class period lasting 50 minutes. This made it possible to test them on all three parts, which took approximately 40 minutes. Since the university students did not perform the experiment during a class period (but e.g. at home), they were asked to complete only two parts, which took approximately 25 minutes.

The study followed the General Ethics Protocol of the Faculty Psychology and Educational Sciences at Ghent University. This means that taking part was not expected to involve risks, that the data would be anonymized, that students gave informed consent and knew they could stop at any moment without consequences. The participants were also debriefed at the end.

The experiment started with a 'welcome and introduction screen' that gave an overview of the different test parts and what the students had to do in each part. After the students entered their name (which was only used for analysis purposes), they could continue to the next screen.

On the second screen, the participants were asked to complete some information about their gender, age, the group they belong to (a high school student/university student or someone who the weblink was sent to) and their self-perceived knowledge of French ('I do not know any French', 'I am able to produce and comprehend a couple of sentences but I cannot have a conversation with a person who speaks French', 'I am quite able to have a conversation with someone who speaks French', 'I can have conversations with ease, but it 
is clear that French is not my first language' or 'French is my first language'). After completing the information, the participant could move on to the next screen.

The third screen provided information about the first test part, the new C-test. The participants were informed of the fact that some words would be missing the last half (or slightly more in case of words with uneven length) and they had to complete the words. They were also told that they could skip words if they did not know the answer and that they were not expected to know all the answers. They had 15 minutes to complete as much as possible. Next, the participants could fill in three example sentences with immediate feedback (Figure I). By means of the example sentences it was explained again that the second halves of the incomplete words (the blanks) had to be filled in.

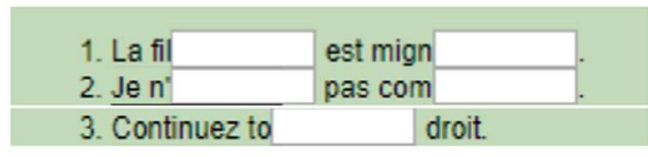

Figure I. Example sentences.

The five paragraphs of the C-test were given simultaneously (Figure II), so that participants could easily go from one paragraph to the next (and back). Participants were informed that the maximum time was 15 mins. 


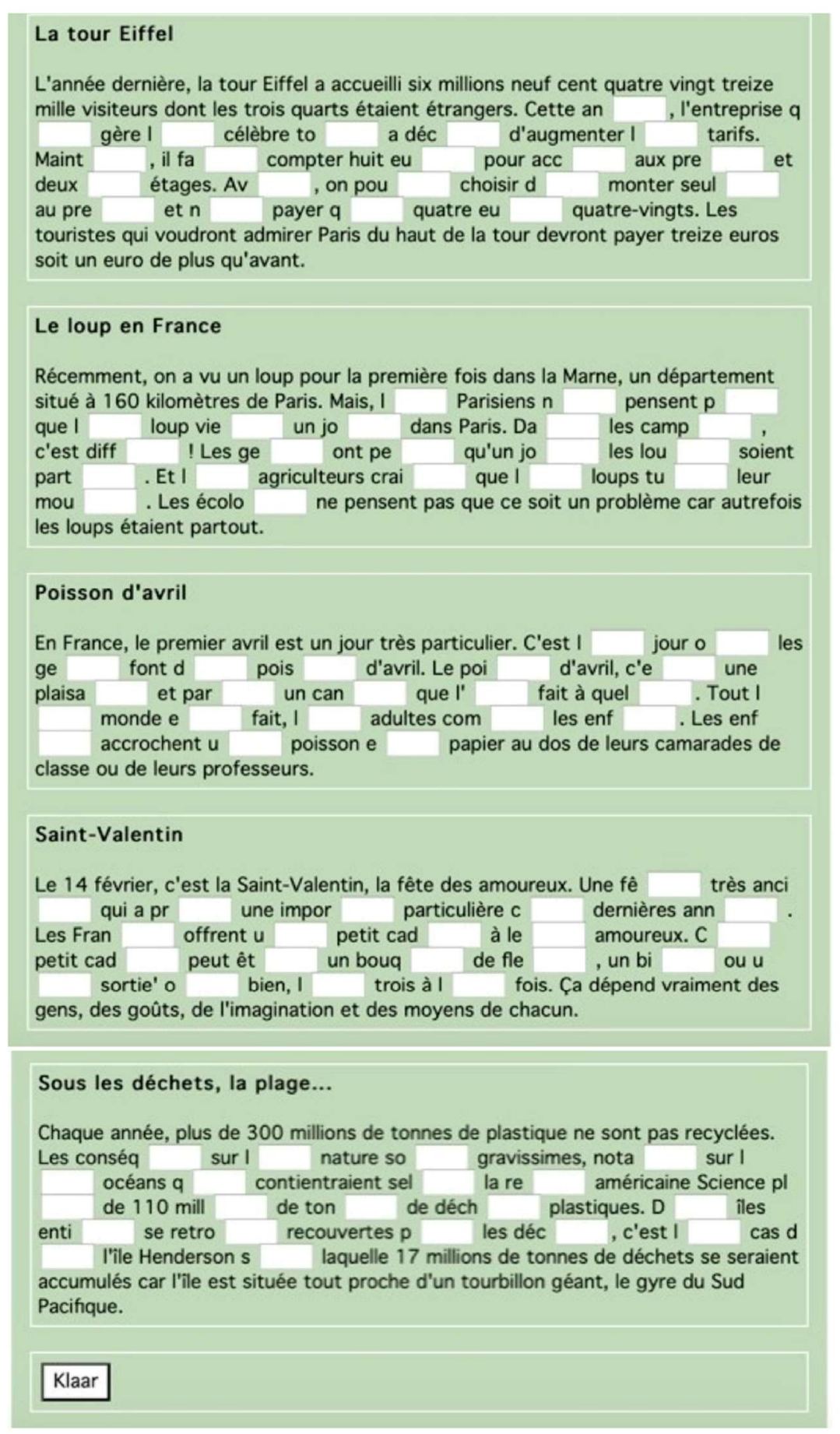

Figure II. The new C-test.

Once the participant had completed all paragraphs, the next screen was reached (or appeared automatically if the time window of 15 minutes had passed). This screen gave participants the opportunity to take a short break and then to continue with the second test the existing C-test (Figure III). As mentioned before, the second C-test was not included for the university students. They went straight to Lextale-FR. 


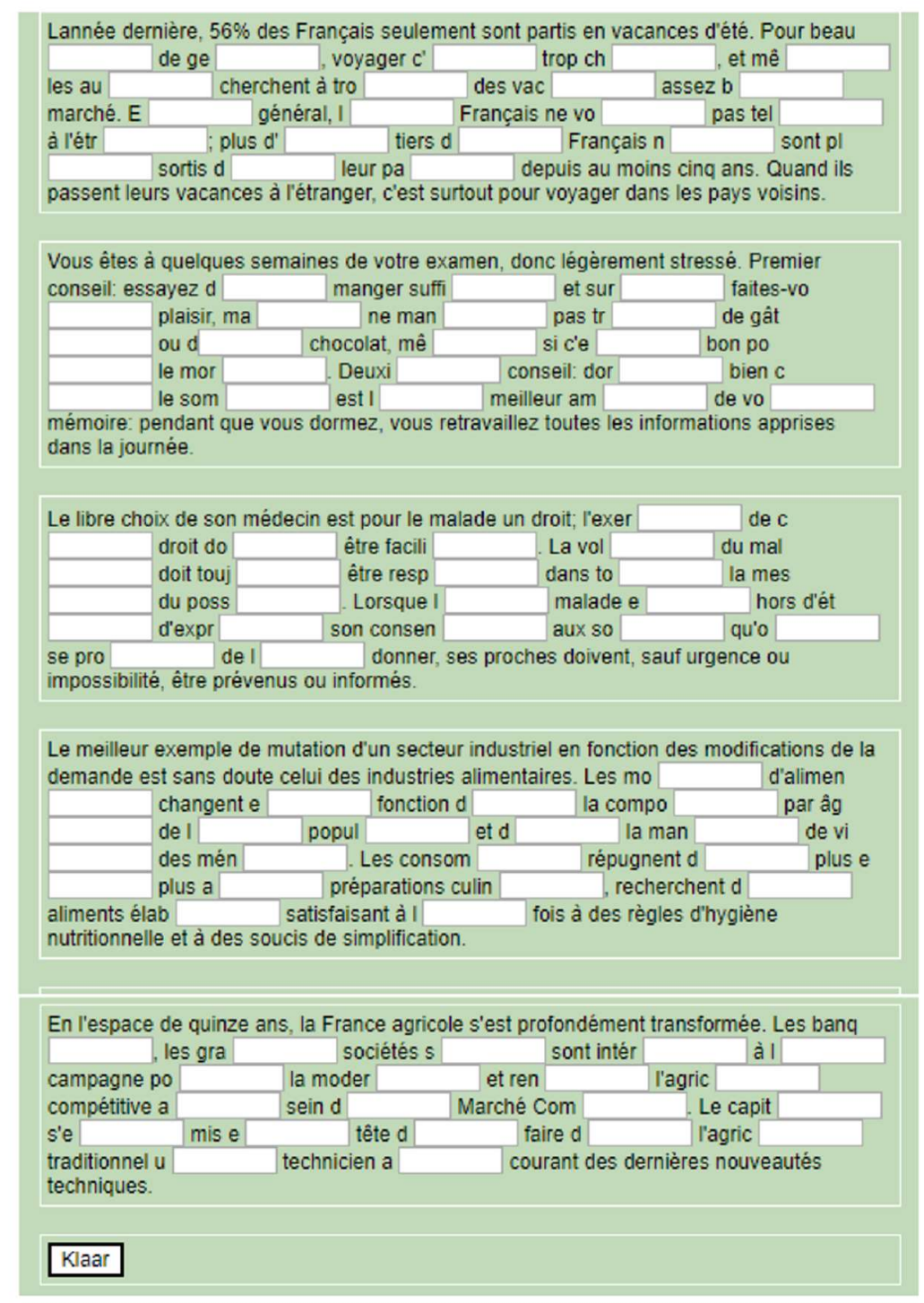

Figure III. The existing C-test.

After the second C-test, the participants were given the opportunity to take a(nother) break before continuing with Lextale-FR. The test started with instructions, explaining the participants that not all letter strings were existing French words and that they were expected to indicate yes to the words they recognized. Participants had to judge each of the 84 letter strings on being an existing French word (by indicating 'true') or a fake 'non-word'. For words they did not recognize, the participants were encouraged to leave the answer on 'false'. In contrast to the C-test(s), there was no time restriction for this part of the test. All words were presented on a single page (that could be scrolled), together with the true/false options 
(see Figure IV). The default option was false and participants were asked to change the answer to true for the words they recognized. Participants could complete the test at their own pace (which was 10 minutes on average) before moving on to the final screen. All participants saw the stimuli in the same order.

\begin{tabular}{|c|c|}
\hline cheveux & echt $\odot$ vals \\
\hline soumon & echt $\odot$ vals \\
\hline cloche & echt 1 vals \\
\hline fascine & echt $\odot$ vals \\
\hline huif & echt $\odot$ vals \\
\hline semonce & echt $\odot$ vals \\
\hline canoter & echt $\odot$ vals \\
\hline infâme & echt $\odot$ vals \\
\hline fourmi & echt $\odot$ vals \\
\hline cadenas & echt $\odot$ vals \\
\hline racaille & echt $\odot$ vals \\
\hline pourcine & echt $\odot$ vals \\
\hline oeillet & echt $\odot$ vals \\
\hline raplaner & echt $\odot$ vals \\
\hline plaiser & echt $\odot$ vals \\
\hline cerveler & echt $\odot$ vals \\
\hline endifier & echt $\%$ vals \\
\hline jamain & echt $\odot$ vals \\
\hline ennemi & echt $\odot$ vals \\
\hline pouce & echt $\odot$ vals \\
\hline metter & echt $\odot$ vals \\
\hline fosse & echt $\odot$ vals \\
\hline inciter & echt 1 vals \\
\hline salière & echt $\odot$ vals \\
\hline fouet & echt $\odot$ vals \\
\hline cessure & echt $\odot$ vals \\
\hline clouer & echt $\odot$ vals \\
\hline mappemonde & echt $\odot$ vals \\
\hline gloque & echt $\odot$ vals \\
\hline lézard & echt $\odot$ vals \\
\hline sacher & echt $\odot$ vals \\
\hline nouer & echt 1 vals \\
\hline occire & echt $\odot$ vals \\
\hline écouce & echt $\odot$ vals \\
\hline osseaux & echt $\odot$ vals \\
\hline rejoute & echt $\odot$ vals \\
\hline escroc & echt $\odot$ vals \\
\hline hache & echt $\odot$ vals \\
\hline parchance & echt $\odot$ vals \\
\hline pinceau & echt $\odot$ vals \\
\hline poisson & echt $\odot$ vals \\
\hline robinet & echt $\odot$ vals \\
\hline amadouer & echt $\odot$ vals \\
\hline
\end{tabular}




\begin{tabular}{|l|l|}
\hline peigne & echt $\odot$ vals \\
retruire & echt $\odot$ vals \\
crayon & echt $\odot$ vals \\
sentuelle & echt $\odot$ vals \\
alourdir & echt $\odot$ vals \\
marteau & echt $\odot$ vals \\
esquif & echt $\odot$ vals \\
treillage & echt $\odot$ vals \\
dauphin & echt $\odot$ vals \\
orgueil & echt $\odot$ vals \\
amorce & echt $\odot$ vals \\
cintre & echt $\odot$ vals \\
chameau & echt $\odot$ vals \\
bouton & echt $\odot$ vals \\
capeline & echt $\odot$ vals \\
lanière & echt $\odot$ vals \\
honteur & echt $\odot$ vals \\
abêtir & echt $\odot$ vals \\
fenétre & echt $\odot$ vals \\
écureuil & echt $\odot$ vals \\
caddie & echt $\odot$ vals \\
détume & echt $\odot$ vals \\
oeuiller & echt $\odot$ vals \\
balai & echt $\odot$ vals \\
prioche & echt $\odot$ vals \\
vicelard & echt $\odot$ vals \\
joueux & echt $\odot$ vals \\
agire & echt $\odot$ vals \\
éventail & echt $\odot$ vals \\
boutard & echt $\odot$ vals \\
panier & echt $\odot$ vals \\
citrouille & echt $\odot$ vals \\
bouilloire & echt $\odot$ vals \\
parir & echt $\odot$ vals \\
remporter & echts \\
\hline
\end{tabular}

Figure IV. Lextale-FR $(\mathrm{echt}=$ real; vals $=$ false $)$

On the final screen the participants were thanked for their participation. They were given their Lextale-FR score and told that a score of $20 \%$ or higher was good for a French L2 
speaker. The participants were also invited to send an email to the experimenter if they wanted further information.

Throughout the test, the instructions were given in Dutch to make sure there were no differences in understanding between participants.

\section{Results}

\section{Coding procedure}

A file with the data is available at https://osf.io/sqmw9/. In line with Klein-Braley and Raatz (1984), the C-test was coded binary: 1 for an entirely correct response, 0 for everything else $(\max =100)$. In the few cases with two acceptable answers (singular/plural) both options were considered correct. Lextale-FR was scored as recommended by Brysbaert (2013): score = number of yes responses to French words minus twice the number of yes responses to nonwords. So, a participant who responded true to 20 French words and to 1 nonwords, would get the score: $20-2 * 1=18$ out of 56 .

\section{Descriptive statistics}

First we calculated the summary statistics for the two groups on the three tests (Table I). These show that no test had a floor or a ceiling effect. They also show that the university students scored on average higher than the high school students, with large effect sizes (New C-test: $d$ $=1.9,95 \%$ confidence interval $[1.3-2.5]$; Lextale-FR: $d=1.7[1.2-2.4])$. At the same time, no university student reached the maximum score, despite the fact that they studied French. This guarantees that the tests can be used for French L2 students in higher education. 
The Lextale-FR scores were lower than expected for the high-school students. As it happens, when corrected for guessing of non-words, they barely recognized 1-2 words on average. The first-year university students performed slightly better than the Dutch-French university students tested by Brysbaert (2013), who reported an average score of $8.3(\mathrm{SD}=11.6)$. This difference could be expected given that the present students were reading French, whereas this was not true for the students tested by Brysbaert (2013).

Table I. Descriptive statistics for the various groups and tests.

Tableau I. Statistiques descriptives des différents groupes et tests.

\begin{tabular}{|c|c|c|c|c|c|c|c|}
\hline Group & Test & Mean & SD & Median & PC10 & PC90 & $\begin{array}{l}\text { Highest } \\
\text { Score }\end{array}$ \\
\hline \multirow[t]{4}{*}{$\begin{array}{l}\text { High- } \\
\text { school }\end{array}$} & $\begin{array}{l}\text { New C-test } \\
(\max =100)\end{array}$ & 42 & 14 & 43 & 24 & 62 & 74 \\
\hline & $\begin{array}{l}\text { Ex. C-test } \\
(\max =100)\end{array}$ & 40 & 13 & 38 & 22 & 58 & 73 \\
\hline & $\begin{array}{l}\text { Lextale-FR } \\
(\max =56)\end{array}$ & 1 & 6 & 2 & -6 & 9 & 22 \\
\hline & $\begin{array}{l}\text { Subjective } \\
\text { estimate } \\
(\max =5)\end{array}$ & 2 & 1 & 2 & 1 & 2 & 4 \\
\hline University & $\begin{array}{l}\text { New C-test } \\
(\max =100)\end{array}$ & 69 & 12 & 72 & 47 & 82 & 82 \\
\hline
\end{tabular}




\begin{tabular}{|l|l|l|l|l|l|l|l|}
\hline & $\begin{array}{l}\text { Lextale-FR } \\
(\max =56)\end{array}$ & 13 & 6 & 14 & 6 & 20 & 25 \\
\hline $\begin{array}{l}\text { Subjective } \\
\text { estimate } \\
(\max =5)\end{array}$ & 2 & 1 & 3 & 1 & 3 & 4 \\
\hline
\end{tabular}

Notes: - PC10 = percentile 10; PC90 = percentile 90

- Subjective estimates: 1 = 'I do not know any French'; 2 = 'I am able to produce and comprehend a couple of sentences but I cannot have a conversation with a person who speaks French'; 3 = 'I am quite able to have a conversation with someone who speaks French'; 4 = 'I can have conversations with ease, but it is clear that French is not my first language'; $5=$ 'French is my first language'.

\section{Reliability (internal consistency)}

To check the reliability of the new- and the existing C-test, the intraclass correlation coefficient ICC2 was calculated for both tests (Table II). This is a measure of internal consistency, based on the five scores of the individual paragraphs. An ICC2 of .75 or more is considered high (Koo \& Li, 2016). To increase comparability, we calculated reliability only for the high school students, who completed both C-tests. For the new C-test ICC2 was .79 (high). For the existing C-test ICC2 was .67 (moderate to high). Further analysis indicated that the correlations with the last paragraphs were not lower than the correlations among the first paragraphs, suggesting that participants, in line with the instructions, in the first pass skipped the words they did not know and only returned to them after they had gone through the entire test.

Table II. ICC2 of both C-tests.

Tableau II. ICC2 des deux C-tests.

\begin{tabular}{|l|c|c|c|}
\hline Test & $\underline{\mathbf{n}}$ & $\underline{\text { ICC2 }}$ & $\underline{\text { Interpretation }}$ \\
\hline New C-test & 115 & .79 & high \\
\hline Existing C-test & 115 & .67 & moderate \\
\hline
\end{tabular}


To check the reliability of Lextale-FR, we had to take into account that the score consisted of a combination of hits and false alarms. The easiest way to do this was to calculate scores on the first half of the test and on the second half. Then we could calculate split-half correlation and correct it with the Spearman-Brown formula for length attenuation. This is again a measure of internal consistency. The split-half correlation was high $(r=.74, p<.001)$. After applying the Spearman-Brown formula/correction $(2 *$ correlation/(1+correlation $))$, reliability was .85 , which is good (Table III), despite the low scores of the high-school students. Against expectation, the split-half correlation was the same when the sample was limited to the high school students $(r=.75$; corrected $r=.86)$.

Table III. Split-half correlation and Spearman-Brown correction Lextale-FR.

Tableau III. Corrélation Split-half et correction de Spearman-Brown Lextale-FR.

\begin{tabular}{|l|c|c|c|}
\hline Correlation/correction & $\underline{\mathbf{n}}$ & $\underline{\mathbf{R}}$ & $\underline{\text { Interpretation }}$ \\
\hline Split-half & 129 & .74 & high \\
\hline Spearman-Brown & 129 & .85 & high \\
\hline
\end{tabular}

\section{Item analysis of the C-tests}

Item reliability analysis (more specifically the item-rest correlation, which is the correlation between the item and the sum of the rest of the item scores), was done for both C-tests. In the new C-test only the item 'vienne' correlated negatively with the total scale and should be treated cautiously. In the existing C-test negative correlations were found for the items: 'bon', 'vont', 'suffisamment', 'mesure', 'possible', and 'consentement'. 


\section{Validity}

A first way to test the validity of the tests is to look at their intercorrelations (Table IV). For the two C-tests, this indicates the degree to which two similar tests, developed by independent teams, measure the same construct. This correlation was high $(r=.77)$, certainly when the reliability of the tests is taken into account. Indeed, if we correct for reliability, the theoretically expected correlation is $1.00(.77 / \sqrt{.79 * .67} \approx 1.00)$. This means that both tests measure the same construct. It also means that the scores on the test are not dependent on the texts selected by the two research groups.

Table IV. Correlations between the different tests.

Tableau IV. Corrélations entre les différents tests.

\begin{tabular}{|l|c|c|c|}
\hline Correlation & $\underline{\mathbf{n}}$ & $\underline{\mathbf{r}}$ & $\underline{\text { Interpretation }}$ \\
\hline new- \& existing C-test & 115 & .77 & high \\
\hline new C-test \& Lextale-FR & 115 & .37 & low \\
\hline existing C-test \& Lextale-FR & 115 & .36 & low \\
\hline
\end{tabular}

The correlations between the C-tests and Lextale-FR indicate the extent to which both test formats measure the same construct (latent variable). These correlations are much lower $(\mathrm{r}=$ .36 and $.37, p<.001)$, also when corrected for reliability of the tests involved. This confirms that the C-test measures skills not covered by the Lextale format (form recognition).

Given the rather low correlation between the C-tests and the yes/no format, it becomes interesting to see how well they predict an external criterion. Ideally, we could have included a reading comprehension and/or listening comprehension test, as indicated in the introduction. However, such tests require about 90 mins to get reliable results (e.g., Laufer \& AviadLevitzky, 2017; Schmitt et al., 2011). Therefore, we decided to rely on teachers' end-of-term 
marks. These are an assessment of four months of study and are a high-stakes score communicated to the students (and their parents) at the end of term. For all high school students, the teachers were kind enough to share their marks of the first term. These marks are expressed as percentage scores. Teachers differed in the ways they assessed their students, but surprisingly the differences between schools and classes were rather small, so that not much information was lost by simply looking at the overall correlations (Table V). These show that the correlations between the exam scores and the C-tests $(r=.59, r=.56)$ are significantly higher than the correlation with Lextale-FR $(r=.40 ; z=1.80, p<.05$ one-tailed $)$ for the comparison of Lextale-FR with the existing C-test).

Table V. Correlations between exam scores and the three different tests.

Tableau V. Corrélations entre les résultats des examens et les trois tests différents.

\begin{tabular}{|l|c|c|c|}
\hline Correlation & $\underline{\mathbf{n}}$ & $\underline{\mathbf{r}}$ & $\underline{\text { Interpretation }}$ \\
\hline Exam scores \& new C-test & 115 & .59 & moderate \\
\hline Exam scores \& existing C-test & 115 & .56 & moderate \\
\hline Exam scores \& Lextale-FR & 115 & .40 & low \\
\hline
\end{tabular}

Finally, we can have a look at the correlations between the three different test scores and the participants' self-ratings of French proficiency. As indicated above, the self-perceived knowledge of French was measured by asking to select one of the following alternatives: 'I do not know any French', 'I am able to produce and comprehend a couple of sentences but I cannot have a conversation with a person who speaks French', 'I am quite able to have a conversation with someone who speaks French', 'I can have conversations with ease, but it is clear that French is not my first language' or 'French is my first language'. These five alternatives can be translated to numbers going from 1 to 5 . As can be seen in Table VI, the correlations between test scores and self-ratings were rather low $(r<.3, p<.03)$. The same 
was true for the correlation between self-assessment and exam scores $(r=.25)$. This is in line with the concern that self-ratings are crude and subjective measures (Brysbaert, 2013; Tomoschuk et al., 2018).

Table VI. Correlations between self-rating and objective measures.

Tableau VI. Corrélations entre l'auto-évaluation et les mesures objectives.

\begin{tabular}{|l|c|c|c|}
\hline Correlation & $\underline{\mathbf{n}}$ & $\underline{\mathbf{r}}$ & $\underline{\text { Interpretation }}$ \\
\hline Self-rating \& new C-test & 115 & .28 & low \\
\hline Self-rating \& existing C-test & 115 & .20 & low \\
\hline Self-rating \& Lextale-FR & 115 & .21 & low \\
\hline Self-rating \& exam & 115 & .25 & low \\
\hline
\end{tabular}

\section{Discussion}

The present study was designed to validate a French C-test for language assessment. The test was developed on the basis of existing French paragraphs, which were chosen carefully and with increasing difficulty. To check the quality of the test, we compared it to a C-test that had been proposed by another research group (Raatz et al., 2006), to a yes/no vocabulary test (Lextale-FR; Brysbaert, 2013), and to the students' end-of-term marks.

A total of 115 senior high school students and 14 more advanced university students ‘Applied Linguistics - French' participated. As expected (David, 2008), the university students performed much better, both on the C-test and on Lextale-FR, but they were not yet at ceiling level.

The C-test we developed does well on the validation criteria we set out: It has a high internal consistency, it correlates well with the parallel C-test, and it predicts French school marks rather well. As a matter of fact, due to our validation of the Raatz et al. (2006) test, the 
present manuscript includes two C-tests that can be used interchangeably. It must be kept in mind, though, that the Raatz et al. (2006) test is slightly less reliable (Table II).

Our findings replicate previous reports of high correlations between C-test scores and educational outcomes (Daller et al., 2020; Eckes \& Grotjahn, 2006), which are higher than the correlations between yes/no vocabulary scores and educational outcomes (Harsch \& Hartig, 2015; McLean et al., 2020). This means that the C-test is a particularly interesting instrument in educational settings. At the same time, the rather low correlation with the yes/no vocabulary test (also reported by Harsch \& Hartig, 2015) suggests that the C-test is influenced by other latent variables than the yes/no vocabulary test. In a review of the literature, Daller et al. (2020) propose three possible skills. First, the C-test could additionally measure crystallized intelligence. Crystallized intelligence refers to information stored in memory, of which vocabulary is a prime example (included in nearly every intelligence test), but which extends to all possible stored knowledge of the world. Second, because of the time constraint, the C-test may be influenced by processing speed (typically involved in fluent intelligence). Finally, the C-test may also be a better measure of language proficiency, because it not only measures word knowledge but also grammatical knowledge and knowledge about typical word transitions in the language. In addition, it is a recall test rather than a recognition test (Zhang \& Zhang, 2020; McLean et al., 2020).

All in all, we are convinced that the C-test is an important addition to language proficiency assessments in French. In an ideal scenario we will be able to use it in a study in which it is compared to the four formats discussed by Zhang and Zhang (2020) and McLean et al. (2020) and to reading and listening comprehension. Unfortunately, the scale of such a study requires more funding (and more time) than we currently have access to.

Another interesting question is how well the C-test will correlate with performance on a lexical decision task. The English LexTALE test is often used in research on visual word 
recognition to assess participants' language proficiency, and Diependaele et al. (2013) reported a high covariation between visual word recognition data and LexTALE scores. Will the C-test still explain extra variance in lexical decision performance over and above LexTALE scores? If so, what does that imply; if not, what does it say about lexical decision performance? With respect to the rather bad outcome with Lextale-FR, it will also be good to examine to what extent this is due to the test being too difficult for the high-school students we tested. Although the test scored well on internal consistency, it would be better to have values in the mid-range of the test.

A final interesting extension will be to investigate how well the test performs with native French speakers. Given that the C-test was not at ceiling level for the advanced L2 learners (Table I), it is likely to work for L1 speakers as well. If needed, the time of the test could be shortened slightly (e.g., to 14 or 12 mins), although this may further emphasize the speed factor (see Gernsbacher et al., 2020, for arguments against time-limited tests). The alternative is to add one or two paragraphs of the Raatz et al. (2006) test. Our data show that these paragraphs measure the same construct(s).

The C-test we present is free to use for education and research under the Creative Commons license Attribution-NonCommercial. If enough researchers and educators use the test, we can start thinking of performance norms, so that researchers not only have information about the performance of participants relative to the other participants tested, but also relative to the population the participants belong to. The data we collected can only be used for Dutch-French bilinguals in high school. 


\section{References}

Amenta, S., Badan, L., \& Brysbaert, M. (2020). LexITA: A Quick and Reliable Assessment Tool for Italian L2 Receptive Vocabulary Size. Applied Linguistics. Advance publication available at https://doi.org/10.1093/applin/amaa020.

Batista, R., \& Horst, M. (2016). A new receptive vocabulary size test for French. Canadian Modern Language Review, 72(2), 211-233.

Brysbaert, M. (2013). LEXTALE_FR: A fast, free, and efficient test to measure language proficiency in French. Psychologica Belgica, 53, 23-37.

Campbell, D. T., \& Fiske, D. W. (1959). Convergent and discriminant validation by the multitrait-multimethod matrix. Psychological Bulletin, 56(2), 81-105.

Chapelle, C. A. (1994). Are C-tests valid measures for L2 vocabulary research?. Second Language Research, 10(2), 157-187.

Daller, M., Müller, A., \& Wang-Taylor, Y. (2020). The C-test as predictor of the academic success of international students. International Journal of Bilingual Education and Bilingualism, DOI: 10.1080/13670050.2020.1747975.

David, A. (2016). Vocabulary breath in French L2 learners. The Language Learning Journal, 36(2), 167-180.

Diependaele, K., Lemhöfer, K., \& Brysbaert, M. (2013). The word frequency effect in first and second language word recognition: A lexical entrenchment account. Quarterly Journal of Experimental Psychology, 66,843-863.

Eckes, T. \& Grotjahn, R. (2006). A closer look at the construct validity of C-tests. Language Testing, 23(3), 290-325. 
Gernsbacher, M. A., Soicher, R. N., \& Becker-Blease, K. A. (2020). Four empirically based reasons not to administer time-limited tests. Translational Issues in Psychological Science, 6(2), 175-190. https://doi.org/10.1037/tps0000232

Harrington, M., \& Carey, M. (2009). The on-line Yes/No test as a placement tool. System, $37(4), 614-626$.

Harsch, C., \& Hartig, J. (2016). Comparing C-tests and Yes/No vocabulary size tests as predictors of receptive language skills. Language Testing, 33(4), 555-575.

Kidd, E., Donnelly, S., \& Christiansen, M. H. (2018). Individual differences in language acquisition and processing. Trends in Cognitive Sciences, 22(2), 154-169.

Klein-Braley, C. \& Raatz, U. 1984: A survey of research on the C-Test. Language Testing, $1,134-46$.

Koo, T.K. \& Li, M.Y. (2016). A guideline of selecting and reporting intraclass correlation coefficients for reliability research. Journal of Chiropractic Medicine, 15(2), 15563.

Laufer, B., \& Aviad-Levitzky, T. A. M. I. (2017). What type of vocabulary knowledge predicts reading comprehension: Word meaning recall or word meaning recognition? The Modern Language Journal, 101(4), 729-741.

Lemhöfer, K. \& Broersma, M. (2012). Introducing LexTALE: a quick and valid lexical test for advanced learners of English. Behavioral Research Methods, 44(2), 325-343.

McLean, S., Stewart, J., \& Batty, A. O. (2020). Predicting L2 reading proficiency with modalities of vocabulary knowledge: A bootstrapping approach. Language Testing. Advance publication available at DOI: 10.1177/0265532219898380. 
Oller Jr, J. W. (1973). Cloze tests of second language proficiency and what they measure 1. Language Learning, 23(1), 105-118.

Peters, E., Velghe, T., \& Van Rompaey, T. (2019). The VocabLab tests: The development of an English and French vocabulary test. ITL-International Journal of Applied Linguistics, 170(1), 53-78.

Raatz, U., Grotjahn, R. \& Wockenfuß, V. (2006). Das TESTATT-Projekt: Entwicklung von C-Tests zur Evaluation des Fremdsprachenlernerfolgs. In R. Grotjahn (Ed.), Der CTest: Theorie, Empirie, Anwendungen/The C-Test: Theory, empirical research, applications (pp. 85-99). Frankfurt, Germany: Peter Lang.

Reips, U. D., \& Neuhaus, C. (2002). WEXTOR: A Web-based tool for generating and visualizing experimental designs and procedures. Behavior Research Methods, Instruments, \& Computers, 34(2), 234-240.

Schmitt, N., Jiang, X., \& Grabe, W. (2011). The percentage of words known in a text and reading comprehension. The Modern Language Journal, 95(1), 26-43.

Schmitt, N., Nation, P., \& Kremmel, B. (2020). Moving the field of vocabulary assessment forward: The need for more rigorous test development and validation. Language Teaching, 53(1), 109-120.

Tomoschuk, B., Ferreira, V. S., \& Gollan, T. H. (2018). When a seven is not a seven: Selfratings of bilingual language proficiency differ between and within language populations. Bilingualism: Language and Cognition, 15, 1-21.

Webb, S., \& Nation, P. (2017). How vocabulary is learned? Oxford University Press.

Zhang, S., \& Zhang, X. (2020). The relationship between vocabulary knowledge and L2 reading/listening comprehension: A meta-analysis. Language Teaching Research. Advance publication available at DOI: 10.1177/1362168820913998. 


\section{Appendix A}

Correction key of the new C-test.

$\mathrm{C} 1$

\section{$\underline{\text { La tour Eiffel }}$}

L'année dernière, la tour Eiffel a accueilli six millions neuf cent quatre-vingt-treize mille visiteurs dont les trois quarts étaient étrangers. Cette année, l'entreprise qui gère la célèbre tour a décidé d'augmenter les tarifs. Maintenant, il faut compter huit euros pour accéder aux premier et deuxième étages. Avant, on pouvait choisir de monter seulement au premier et ne payer que quatre euros quatre-vingts. Les touristes qui voudront admirer Paris du haut de la tour devront payer treize euros soit un euro de plus qu'avant.

$\mathrm{C} 2$

\section{$\underline{\text { Le Loup en France }}$}

Récemment, on a vu un loup pour la première fois dans la Marne, un département situé à 160 kilomètres de Paris. Mais, les Parisiens ne pensent pas que le loup vienne un jour dans Paris. Dans les campagnes, c'est différent! Les gens ont peur qu'un jour les loups soient partout. Et les agriculteurs craignent que les loups tuent leurs moutons. Les écologistes ne pensent pas que ce soit un problème car autrefois les loups étaient partout. 


\section{$\underline{\text { Poisson d'avril }}$}

En France, le premier avril est un jour très particulier. C'est le jour où les gens font des poissons d'avril. Le poisson d'avril, c'est une plaisanterie et parfois un canular que l'on fait à quelqu'un. Tout le monde en fait, les adultes comme les enfants. Les enfants accrochent un poisson en papier au dos de leurs camarades de classe ou de leurs professeurs.

$\mathrm{C} 4$

\section{$\underline{\text { Saint-Valentin }}$}

Le 14 février, c'est la Saint-Valentin, la fête des amoureux. Une fête très ancienne qui a pris une importance particulière ces dernières années. Les Français offrent un petit cadeau à leur amoureux. Ce petit cadeau peut être un bouquet de fleurs, un bijou ou une sortie... ou bien, les trois à la fois. Ça dépend vraiment des gens, des goûts, de l'imagination et des moyens de chacun.

C5

\section{$\underline{\text { Sous les déchets, la plage... }}$}

Chaque année, plus de 300 millions de tonnes de plastique ne sont pas recyclées. Les conséquences sur la nature sont gravissimes, notamment sur les océans qui contiendraient selon la revue américaine Science plus de 110 millions de tonnes de déchets plastiques. Des îles entières se retrouvent recouvertes par les déchets, c'est le cas de l'île Henderson sur laquelle 17 millions de tonnes de déchets se seraient accumulés car l'île est située tout proche d'un tourbillon géant, le gyre du Sud Pacifique. 


\section{Appendix B}

Correction key of the existing C-test (Raatz et al. 2006).

C6

En l'espace de quinze ans, la France agricole s'est profondément transformée. Les banques, les grandes sociétés se sont intéressées à la campagne pour la moderniser et rendre l'agriculture compétitive au sein du Marché Commun. Le capitalisme s'est mis en tête de faire de l'agriculteur traditionnel un technicien au courant des dernières nouveautés techniques.

\section{C7}

L'année dernière, 56\% des Français seulement sont partis en vacances d'été. Pour beaucoup de gens, voyager c'est trop cher, et même les autres cherchent à trouver des vacances assez bon marché. En général, les Français ne vont pas tellement à l'étranger; plus d'un tiers des Français ne sont plus sortis de leur pays(trie) depuis au moins cinq ans. Quand ils passent leurs vacances à l'étranger, c'est surtout pour voyager dans les pays voisins.

$\mathrm{C} 8$

Vous êtes à quelques semaines de votre examen, donc légèrement stressé. Premier conseil: essayez de manger suffisamment et surtout faites-vous plaisir, mais ne mangez pas trop de gâteau(x) ou de chocolat, même si c'est bon pour le moral. Deuxième conseil: dormez bien car le sommeil est le meilleur ami de votre mémoire: pendant que vous dormez, vous retravaillez toutes les informations apprises dans la journée. 
Le libre choix de son médecin est pour le malade un droit; l'exercice de ce droit doit être facilité. La volonté du malade doit toujours être respectée dans toute la mesure du possible. Lorsque le malade est hors d'état d'exprimer son consentement aux soins qu'on se propose de lui donner, ses proches doivent, sauf urgence ou impossibilité, être prévenus ou informés.

$\mathrm{C} 10$

Le meilleur exemple de mutation d'un secteur industriel en fonction des modifications de la demande est sans doute celui des industries alimentaires. Les modes d'alimentation changent en fonction de la composition par âge(s) de la population et de la manière de vivre des ménages. Les consommateurs répugnent de plus en plus aux préparations culinaires, recherchent des aliments élaborés satisfaisant à la fois à des règles d'hygiène nutritionnelle et à des soucis de simplification. 


\section{Appendix C}

Selected stimuli of the LexTALE_FR (in the order of the list) with their English translations.

cheveux (hair); soumon (NW); cloche (bell); fascine (faggot, fascinate); huif (NW); semonce (lecture); canoter (boating); infâme (infamous); fourmi (ant); cadenas (padlock); racaille (riffraff); pourcine (NW); œillet (carnation); raplaner (NW); plaiser $(\mathrm{NW})$; cerveler $(\mathrm{NW})$; endifier (NW); jamain (NW); ennemi (enemy); pouce (thumb); metter (NW); fosse (pit); inciter (encourage); salière (salt shaker); fouet (whip); cessure (NW); clouer (nail); mappemonde (globe); gloque (NW); lézard (lizard); sacher (NW); nouer (establish); occire (slay); écouce (NW); osseaux (NW); rejoute (NW); escroc (crook); hache (ax); parchance (NW); pinceau (brush); poisson (fish); robinet (tap); amadouer (coax); peigne (comb); retruire (NW); crayon (pencil); sentuelle (NW); alourdir (to make heavy); marteau (hammer); esquif (skiff); treillage (trellis); dauphin (dolphin); orgueil (pride); amorce (prime); cintre (hanger); chameau (camel); bouton (button); capeline (wide-brimmed hat); lanière (strap); honteur (NW); abêtir (stultify); fenêtre (window); écureuil (squirrel); caddie (caddy); détume (NW); oeuiller (NW); balai (broom); prioche (NW); vicelard (pervert); joueux (NW); agire (NW); éventail (range); boutard (NW); panier (basket); citrouille (pumpkin); bouilloire (kettle); parir (NW); remporter (win); procoreux (NW); tanin (tannin); église (church); indicible (unspeakable); réporce (NW); mignon (cute). 